\title{
Plasticity of Developing Cerebellar Cells in vitro Studied with Antibodies Against the NG2 Antigen
}

\author{
Joel M. Levine ${ }^{1}$ and William B. Stallcup ${ }^{2}$ \\ 'Department of Neurobiology and Behavior, State University of New York at Stony Brook, Stony Brook, New York 11794, \\ and ${ }^{2} \mathrm{La}$ Jolla Cancer Research Foundation, La Jolla, California 92037
}

The NG2 antigen, a chondroitin-sulfate proteoglycan, is a cell surface marker for a class of smooth protoplasmic astrocytes found throughout the brain and at high frequency in the cerebellar molecular layer (Levine and Card, 1987). To study the development of the cerebellar astrocytes at the level of the single cell, we have analyzed the distribution of the NG2 antigen by indirect immunofluorescence in dissociated cell cultures prepared from postnatal cerebella and compared that distribution to the distribution of several other cell surface and intracellular antigens that identify specific cell types in cultures of nervous tissue.

When cerebellar cells from $5 \mathrm{~d}$ rat pups were grown in a medium containing $10 \%$ fetal calf serum, the NG2-labeled cells, which constituted $0.1-1.0 \%$ of the total glial cells present, contained glial fibrillary acidic protein (GFAP)-immunoreactive filaments and bound monoclonal antibody A2B5, a surface marker for neurons and some astrocytes. Approximately $30 \%$ of the NG2-labeled cells were also labeled with tetanus toxin, an additional surface marker for neurons and immature astrocytes. Less than $2 \%$ of the cells were labeled with antibodies against galactocerebroside or with monoclonal antibody 01 , both of which are surface markers for oligodendrocytes. About half the NG2-labeled cells exhibited high-affinity uptake of ${ }^{3} \mathrm{H}-\mathrm{GABA}$, and this uptake was partially inhibited by both $\beta$-alanine and DABA. Thus, the NG2 antigen is a cell surface marker for a subpopulation of the type II or fibrous astrocytes present in the cultures. When the cerebellar cells were grown in a chemically defined, serum-free medium, the NG2-labeled cells had a stellate morphology and between $50-60 \%$ of the cells bound tetanus toxin. Although almost all the cells bound antibody A2B5, less than $5 \%$ of the cells expressed either of the oligodendrocyte surface markers or GFAP immunoreactivity. As was the case with cells grown in serum-containing medium, $60 \%$ of the NG2-labeled cells had high-affinity uptake of ${ }^{3} \mathrm{H}-\mathrm{GABA}$. However, this uptake was inhibited by DABA but not by $\beta$-alanine. This phenotype may be the in vitro analog of the NG2-labeled, filament-lacking, smooth protoplasmic astrocytes identified in the intact adult cerebellum. The expression of these 2 phenotypes could be reversed by switching the tissue culture medium within $5 \mathrm{~d}$ of plating the cells.

Received Aug. 19, 1986; revised Feb. 4, 1987; accepted Feb. 19, 1987

We thank L. Beasley and P. Flynn for technical assistance. We also thank Drs. D. Paulin and M. Schachuer for their gifts of antibodies and Drs. S. Haleguoa, J.

White and M. C. Raff for their comments on the manuscript. This work was supported by NIH Grants 21198 (to J.M.L.) and 21990 (to W.B.S.).

Correspondence should be addressed to Dr. Levine at the above address.

Copyright (c) 1987 Society for Neuroscience $0270-6474 / 87 / 092721-11 \$ 02.00 / 0$
These results demonstrate that the in vitro environment can influence the phenotypic properties expressed by developing cerebellar astrocytes and suggest that smooth protoplasmic astrocytes may be developmentally related to glial cells of the 0-2A lineage.

The development of markers specific for the different classes of cells comprising the CNS has provided a means of identifying cells in primary cultures of nervous tissue and following their development over time. Studies employing tetanus toxin binding as a marker for neurons (Mirsky et al., 1977), anti-glial fibrillary acidic protein (GFAP) staining for astrocytes (Bignami et al., 1972) and anti-galactocerebroside (GC) labeling for oligodendrocytes (Raff et al., 1978) have shown that the time course of the appearance of these different classes of cells in primary tissue culture is similar to the appearance of the same cell types in vivo (Abney et al., 1981). Other cell surface markers, such as the $O$ antigens (Sommer and Schachner, 1981) have been used to analyze the development of oligodendrocytes in vitro (Schachner et al., 1981). The power of these immunological approaches is cxcmplificd by the studics of Raff and associates, who have shown that in developing optic nerve, fibrous astrocytes and oligodendrocytes develop from a common precursor cell (Raff et al., 1983b; Temple and Raff, 1985).

The NG2 antigen is a high molecular weight chondroitinsulfate proteoglycan found in the developing and mature brain (Stallcup et al., 1983). Previous studies have demonstrated that the NG2 antigen is expressed on a limited number of clonal cell lines, all of which have properties associated with both neurons and glial cells (Wilson et al., 1981). In primary cultures prepared from embryonic brain or postnatal cerebellum, the anti-NG2 antibodies recognized a subpopulation of the cells present, and these cells bound tetanus toxin, a neuronal marker, and contained GFAP-like intermediate filaments, a property of astrocytes (Stallcup, 1981). These in vitro studies suggested that the NG2 antigen might be a marker for a class of immature cells capable of developing into either neurons or astrocytes. In the adult cerebellum, however, the NG2 antigen is associated with a class of smooth protoplasmic astrocytes found at high frequency in the molecular layer and is not associated with the inhibitory interneurons that comprise the cerebellar cortex (Levine and Card, 1987). In those in situ immunofluorescence studies, we noted that a large number of cells throughout the developing cerebellum were labeled with the anti-NG2 antibodies, leaving open the possibility that some of the NG2-labeled cells might differentiate along pathways other than that leading to smooth protoplasmic astrocytes. 


\begin{tabular}{|c|c|c|c|}
\hline Antibody (probe) & Antigen (ligand) & Cellular distribution & Reference(s) \\
\hline Tetanus toxin & $\mathrm{GD}_{1 \mathrm{~b}}, \mathrm{GT}_{1}$ ganglioside & Neurons, immature astrocytes & Mirsky et al., 1977; Raff et al., 1983b \\
\hline Mab A2B5 & GQ gangliosides & Neurons, immature astrocytes & $\begin{array}{l}\text { Eisenbarth et al., 1979; Raff et al., 1983b; } \\
\text { Schnitzer and Schachner, } 1982\end{array}$ \\
\hline Mab O1 & $?$ & Oligodendrocytes & Sommer and Schachner, 1981 \\
\hline Mab O4 & ? & Oligodendrocyte precursors & Sommer and Schachner, 1981 \\
\hline Rabbit anti-GC & GC & Oligodendrocytes & Raff et al., 1978 \\
\hline Rabbit anti-GFAP & GFAP intermediatc filaments & Astrocytes & Bignami et al., 1972 \\
\hline Mab anti-vimentin & $\begin{array}{l}\text { Vimentin-type intermediate } \\
\text { filaments }\end{array}$ & $\begin{array}{l}\text { Fibroblasts, immature neurons } \\
\text { and astrocytes }\end{array}$ & Dellagi et al., 1982; Schnitzer et al., 1981 \\
\hline
\end{tabular}

In view of the recent demonstration that environmental conditions can influence the phenotype of developing glial cells ( $R$ aff et al., 1983b), we have reexamined the cellular distribution of the NG2 antigen in cultures prepared from young postnatal cerebellum. Using double-label fluorescence techniques, we asked first whether the NG2-labeled cells expressed markers associated with neurons, astrocytes, or oligodendrocytes and, second, how the expression of these cell-type-specific markers varied as a function of time in culture and culture conditions. We show here that when cerebellar cells are grown in medium containing $10 \%$ fetal calf serum, the NG2-labeled cells have several properties associated with type II or fibrous astrocytes. When grown in a chemically defined, serum-free medium (Bottenstein and Sato, 1979), the NG2-labeled cells express neither astrocytenor oligodendrocyte-specific markers; rather, they appear to resemble the smooth protoplasmic astrocytes we have identified in situ. These studies provide evidence for a degree of phenotypic plasticity among developing cerebellar cells and suggest that smooth protoplasmic astrocytes may comprise a third member of the O-2A lineage family (Raff et al., 1983b).

\section{Materials and Methods}

Tissue culture. Dissociated cerebellar cultures were prepared from postnatal Sprague-Dawley rats as described (Levine et al., 1984). Briefiy, the cerebella were quickly removed and rinsed in HEPES-buffered Dulbecco's Minimal Essential Medium (DMEM; Gibco), and the meninges and major blood vessels were removed. The tissue was minced into small pieces, which were treated with $0.25 \%$ trypsin (Worthington) in calcium-free PBS containing $20 \mu \mathrm{g} / \mathrm{ml}$ DNAse I (Sigma) for 20-30 min at $37^{\circ} \mathrm{C}$. The enzyme solution was removed, and the tissue pieces were rinsed twice in DMEM containing 10\% fetal calf serum (FCS; KC Biologicals). The tissue was dissociated by repeated passage through a series of flame-narrowed Pasteur pipettes; cells were washed, counted, and plated onto poly(L-lysine)-coated $(25 \mu \mathrm{g} / \mathrm{ml}$ in water) $60 \mathrm{~mm}$ tissue culture dishes (Falcon) at a density of $1-1.5 \times 10^{6} /$ dish in a medium consisting of DMEM, 10\% FCS, and $25 \mathrm{mM} \mathrm{K}^{+}$. After $12-18 \mathrm{hr}$, the medium of half the cultures was changed to the chemically defined medium of Bottenstein and Sato (1979).

Antibodies. The derivation and characterization of the rabbit anti$\mathrm{NG} 2$ antisera and 2 monoclonal antibodies (Mab) against the NG2 antigen (D31.10 and D120.43) have been described (Wilson et al., 1981; Stallcup et al., 1983; Levine and Card, 1987). Tetanus toxin was purchased from Calbiochem and horse anti-tetanus toxin was purchased from Connaught Labs Ltd. Rabbit anti-GFAP was purchased from Dako and rabbit anti-GC from Chemicon International. Monoclonal antibodies O1 and O4 (Sommer and Schachner, 1981) were obtained from Dr. M. Schachner and a monoclonal human anti-vimentin antibody (Dellagi et al., 1982) from Dr. D. Paulin. Monoclonal antibody A2B5 (Eisenbarth et al., 1979) was purchased from ATCC. Affinity purified goat anti-rabbit $\mathrm{IgG}$ antibodies were prepared in our laboratory and coupled to either fluorescein or rhodamine. Fluorescein and rhodamine goat anti-mouse IgG and IgM and rhodamine goat anti-human IgM were purchased from Tago; fluorescein goat anti-horse IgG was obtained from Kirkegaard and Perry. Biotinylated horse anti-mouse IgG and IgM and fluorescein avidin DCS were purchased from Vector Labs.

Immunofluorescent labeling. The immunofluorescent staining of living cells in monolayer culture was performed as described (Stallcup, 1981). For Mabs D31.10 and D120.43, a triple sandwich technique was used; cells were treated sequentially with both anti-NG2 antibodies, biotinylated horse anti-mouse diluted 1:100, and FITC avidin DCS diluted 1:500. Intracellular antigens were labeled after fixing the cultures with $95 \%$ ethanol at $-20^{\circ} \mathrm{C}$. Cells were examined and photographed on either a Nikon or Leitz microscope equipped for epifluorescent illumination and phase-contrast optics. For cell counts, at least 15 randomly selected fields were counted in each specimen.

${ }^{3} \mathrm{H}$-GABA uptake and autoradiography. Cells grown on glass coverslips were washed in HEPES-buffered DMEM and incubated in HEPESDMEM containing $10 \mu \mathrm{Ci} / \mathrm{ml}^{3} \mathrm{H}-\mathrm{GABA}$ (New England Nuclear; specific activity, $34.7 \mathrm{Ci} / \mathrm{mmol}$ ). The final GABA concentration was $1.3 \times$ $10^{-7} \mathrm{M}$. After $30 \mathrm{~min}$ at room temperature, the cells were washed 6 times and fixed in $2.5 \%$ glutaraldehyde (Sigma) in PBS for $15 \mathrm{~min}$ at room tempcraturc. For inhibition of uptake, the cells were preincubated for $15 \mathrm{~min}$ in either $2 \mathrm{mM} \beta$-alanine or $1 \mathrm{mM}$ diamino- $n$-butyric acid (DABA, Sigma), and the drugs were also present during the incubation with ${ }^{3} \mathrm{H}-\mathrm{GABA}$. After fixation, the cells were washed 6 times in PBS and treated for $30 \mathrm{~min}$ in HEPES-DMEM containing $10 \%$ FCS to block any active groups generated by the glutaraldehyde. After 3 additional washes in HEPES-DMEM, the cells were treated sequentially with rabbit anti-NG2 diluted 1:50, biotinylated goat anti-rabbit and avidin HRP complex all obtained from Vector Labs. The coverslips were incubated in $3^{\prime} 3^{\prime}$-diaminobenzidine and $\mathrm{H}_{2} \mathrm{O}_{2}$, washed extensively, airdried, glued to microscope slides, and dipped in Kodak NTB-2 emulsion diluted $1: 1$ in water. The autoradiograms were exposed for 7-10 d at $-20^{\circ} \mathrm{C}$, developed, and examined using bright-field illumination.

\section{Results}

Table 1 lists the monoclonal and polyclonal antibodies used in this study. Some of the cell surface probes, such as Mab O1 or rabbit anti-GC are cell-type-specific probes (in this case for oligodendrocytes), whereas other of the antibodies, such as Mab A2B5, have a broader specificity. We also used several antibodies against intermediate filament protein antigens. The GFAP antigen is a specific marker for astrocytes (Bignami et al., 1972), whereas vimentin-containing intermediate flaments are widely distributed and are found in fibroblasts as well as some neurons and astrocytes (Lazerides 1980; Schnitzer et al., 1981). By examining the distribution of these cell surface and intracellular markers in cells bearing the NG2 antigen on their surfaces, we wished to characterize the phenotype of the NG2-labeled cells and examine the developmental potentials of the NG2-labeled cells when grown under different conditions.

\section{Phenotype of the NG2-labeled cells}

We grew postnatal day 5 (PND5) cerebellar cells in either DMEM containing $10 \%$ FCS or in the chemically defined N2 medium 

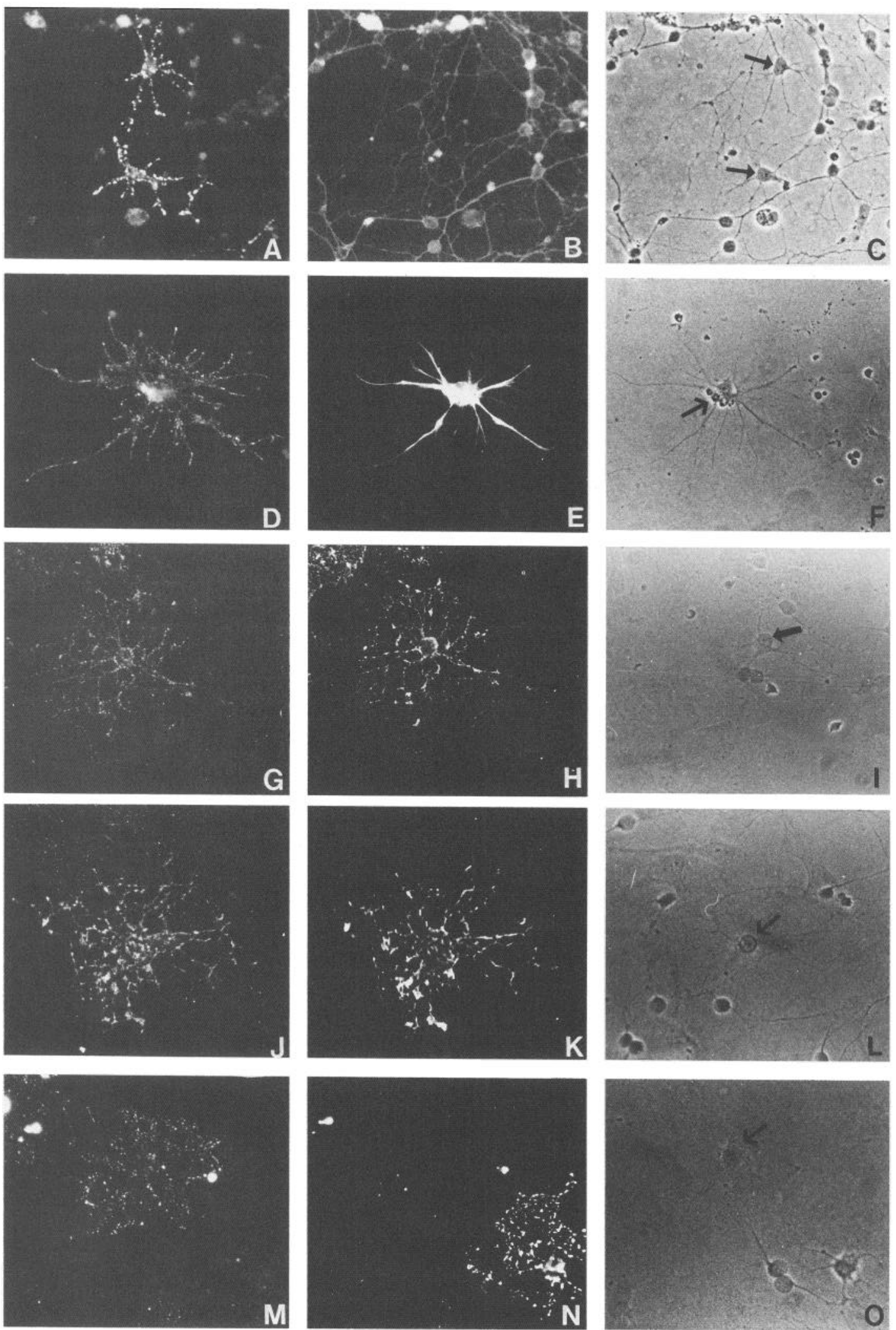

Figure 1. Expression of cell surface and intracellular antigens by NG2-labeled cells in cultures grown in DMEM $+10 \%$ FCS. Cells were labeled with the indicated antibodies as described under Materials and Methods. $A$, Rabbit anti-NG2 label; $B$, tetanus toxin label, the NG2-positive cells are unstained; $C$, phase-contrast, $5 \mathrm{~d}$ in vitro (DIV), $\times 280 ; D$, Mab anti-NG2 label; $E$, rabbit anti-GFAP label; $F$, phase-contrast, 7 DIV, $\times 280$; $G$, rabbit anti-NG2 label; $H$, Mab A2B5 label; $I$, phase-contrast, 7 DIV, $\times 250 ; J$, rabbit anti-NG2 label; $K$, Mab O4 label; $L$, phase-contrast, 5 DIV, $\times 290 ; M$, Mab anti-NG2 label; $N$, rabbit anti-GC label; $O$, phase-contrast, $5 \mathrm{DIV}, \times 260$. The arrows in the phase-contrast photomicrographs indicate the NG2-labeled cells. 


\begin{tabular}{|c|c|c|c|c|c|c|}
\hline DIV & Tetanus toxin & GFAP & $\mathrm{Ol}^{b}$ & GC & $\mathrm{O} 4$ & A2B5 \\
\hline \multicolumn{7}{|c|}{ Cells grown in DMEM containing $10 \%$ FCS } \\
\hline 3 & $49.5 \pm 3.7$ & $20.8 \pm 8.9$ & 1.1 & $0.9 \pm 2.2$ & $33.8 \pm 4.9$ & $98.3 \pm 2.9$ \\
\hline 5 & $40.5 \pm 12.6$ & $65.2 \pm 12.9$ & 0 & $1.7 \pm 1.0$ & $60.8 \pm 5.9$ & $93.4 \pm 1.5$ \\
\hline 7 & $31.5 \pm 10.8$ & $67.8 \pm 17.3$ & 1.4 & $0.9 \pm 1.4$ & $60.5 \pm 17.9$ & $94.6 \pm 2.1$ \\
\hline 10 & $33.0 \pm 5.4$ & $78.4 \pm 8.7$ & ND & ND & ND & ND \\
\hline 15 & $22.8 \pm 6.2$ & $92.7 \pm 1.5$ & ND & ND & ND & ND \\
\hline \multicolumn{7}{|c|}{ Cells grown in N2 medium } \\
\hline 3 & $43.4 \pm 4.5$ & $4.8 \pm 2.4$ & $2.7^{b}$ & $2.8 \pm 1.4$ & $59.0 \pm 8.3$ & $95.8 \pm 3.9$ \\
\hline 5 & $35.0 \pm 2.8$ & $4.4 \pm 2.3$ & 3.5 & $1.0 \pm 1.4$ & $41.5 \pm 16.0$ & $95.7 \pm 4.4$ \\
\hline 7 & $49.2 \pm 3.5$ & $5.1 \pm 2.4$ & 3.8 & $0^{b}$ & $68.5 \pm 14.9$ & $91.5 \pm 7.8$ \\
\hline 10 & $52.7 \pm 12.7$ & $2.8 \pm 1.8$ & ND & ND & ND & ND \\
\hline 15 & $61.6 \pm 7.2$ & $0.8 \pm 1.3$ & ND & ND & ND & ND \\
\hline
\end{tabular}

DIV, days in vitro; $\mathrm{ND}$, not determined.

${ }^{a}$ Data (mean \pm SD) pooled from 6 different experiments. In each experiment between 100-200 cells were counted for each time point.

${ }^{b}$ The low number of labeled cells precluded statistical analysis.

of Bottenstein and Sato (1979). Under both sets of conditions, the NG2-labeled cells were only a subpopulation of the total cells present. Between $0.1-1.0 \%$ of the cerebellar glial cells were labeled with the anti-NG2 antibodies. In our initial series of experiments, we determined whether the NG2-labeled cells were labeled with either tetanus toxin, a probe for the neuronal cell surface, or with antibodies against GFAP, an intracellular marker for astrocytes. As shown in Figure 1 and Table 2, when cerebellar cells were grown in serum-containing medium, there was a progressive increase in the percentage of the NG2-labeled cells that expressed GFAP antigens, so that after 2 weeks in culture, more than $90 \%$ of the NG2-labeled cells contained GFAP-like immunoreactivity (Fig. 1, $D-F$ ). Although about half the NG2-labeled cells bound tetanus toxin at the beginning of the culture period, the percentage of tetanus toxin-labeled, NG2positive cells declined by over half during the 2 week culture period (Fig. 1, $A-C$ ). These observations demonstrate that NG2labeled cells express a phenotypic property of astrocytes when grown in medium containing FCS.

When the cerebellar cells were grown in defined medium without serum, the phenotypic properties of the NG2-labeled cells differed from those expressed in serum-containing medium. As shown in Table 2 and Figure 2, the NG2-labeled cells retained the tetanus toxin binding sites on their surface, with the percentage of tetanus toxin-labeled cells increasing during the 2 week culture period (Fig. $2, A-C$ ). In contrast to the expression of astrocytic properties in serum-containing medium, few if any of the NG2-labeled cells contained GFAP-like immunoreactivity when grown in defined medium (Fig. 2, $D-F$ ).

The morphologies of the NG2-labeled cells also differed under the 2 culture conditions used. In defined medium, NG2-labeled cells developed a stellate appearance with cither short, highly branched processes or with longer, less branched processes. This morphology resembled the appearance of the NG2-labeled cells in situ (Levine and Card, 1987). In serum-containing medium, the NG2-labeled cells had a fuzzy appearance, with many short processes radiating out of the cell body.

In addition to the process-bearing cells analyzed above, the anti-NG2 antibodies also labeled a population of the flat, epitheloid cells common in the cultures. These cells, which for the most part were not stained with the anti-GFAP antibodies, could be distinguished easily from the NG2-labeled cells with processes since the anti-NG2 immunoreactivity was organized into linear arrays across the surfaces of the flat cells as opposed to the punctate appearance of the anti-NG2 staining on the process-bearing cells. The flat cells, which proliferate in serumcontaining medium, could not be induced to adopt a stellate morphology, even after repeated passaging of the cells and growing them in medium containing dibutryl cyclic AMP (data not shown). The flat cells were not included in the present study.

To determine whether the NG2-labeled cells expressed any characteristics of oligodendrocytes, we performed double-label experiments with either a rabbit anti-GC antibody or with Mab O1. Table 2 and Figures 1 and $2, M-O$, show that very few of the NG2-labeled cells bound rabbit anti-GC or Mab O1 in either of the tissuc culturc conditions used. Thus, most of the NG2labeled cells do not express surface antigens characteristic of mature oligodendrocytes.

To investigate the possibility that the GFAP-negative, NG2positive cells present in the cultures might be immature oligodendrocytes or oligodendrocyte precursors, we performed double-label experiments with rabbit anti-NG2 and Mab O4. The $\mathrm{O} 4$ antigen is thought to be a surface marker for immature oligodendrocytes since its expression in vitro precedes the expression of the $\mathrm{Ol}$ antigen, and, with increasing time in culture, the $\mathrm{O} 4$ positive cells become GC positive (Schachner et al., 1981). As shown in Figures 1 and 2, $J_{-} L$, and Table 2, approximately half the NG2-labeled cells bound Mab O4. The expression of the $\mathrm{O} 4$ antigen was not affected significantly by tissue culture conditions. In the serum-containing cultures, between $30-60 \%$ of the NG2-labeled cells were labeled with Mab O4 (Table 2). The NG2-positive, O4-positive cells represented approximately $63 \%$ of all the O4-labeled cells in the cultures. After $7 \mathrm{~d}$ in culture, $67 \%$ of the NG2-labeled cells contained GFAP-immunoreactive filaments, suggesting that some of the O4-labeled cells might contain GFAP filaments. To test this possibility, we performed double-label fluorescent studies using $\mathrm{Mab} \mathrm{O} 4$ and rabbit anti-GFAP. After $7 \mathrm{~d}$ in medium containing serum, between $28-40 \%$ of the O4-labeled cells were colabeled with anti-GFAP (Fig. $3, A-C$ ). Thus, it is likely that some of 

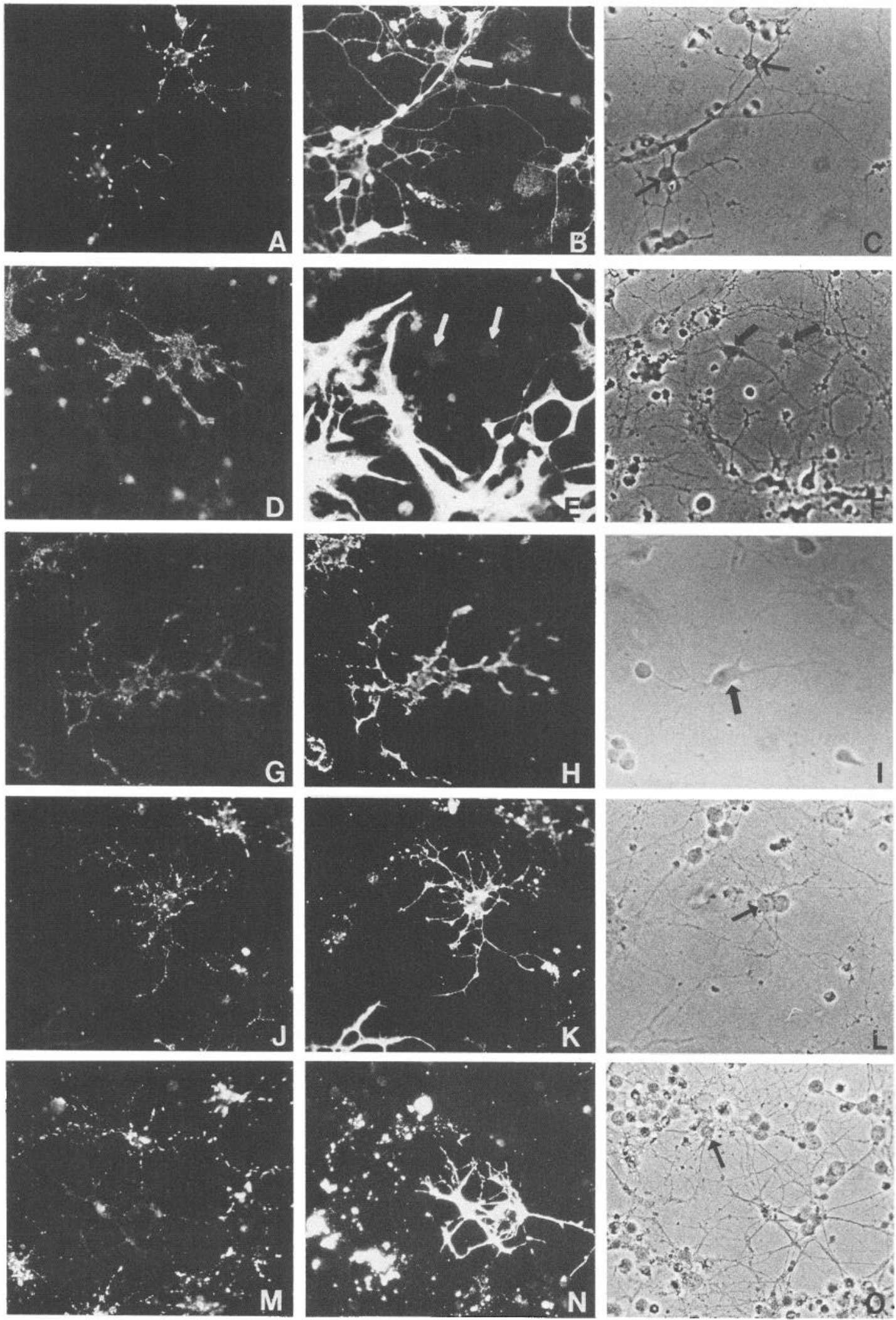

Figure 2. Expression of cell surface and intracellular antigens by NG2-labeled cells in cultures grown in N2 medium. $A$, Rabbit anti-NG2 label. $B$, Tetanus toxin label; the NG2-labeled cells are positive for tetanus toxin. $C$, Phase-contrast, 5 DIV, $\times 280$. The arrows in $B$ and $C$ indicate the NG2-labeled cells. $D$, Mab anti-NG2 label. $E$, Rabbit anti-GFAP label. $F$, Phase-contrast, 7 DIV, $\times 260$. $G$, Rabbit anti-NG2 label. $H$, Mab A2B5 label. I, Phase-contrast, 3 DIV, $\times 330$. $J$, Rabbit anti-NG2 label. $K$, Mab O4 label. $L$, Phase-contrast, 7 DIV, $\times 300 . M$, Rabbit anti-NG2 label. $N$, Mab O1 label. $O$, Phase-contrast, $7 \mathrm{DIV}, \times 280$. The arrows in the phase-contrast photomicrographs indicate the NG2-labeled cells. 

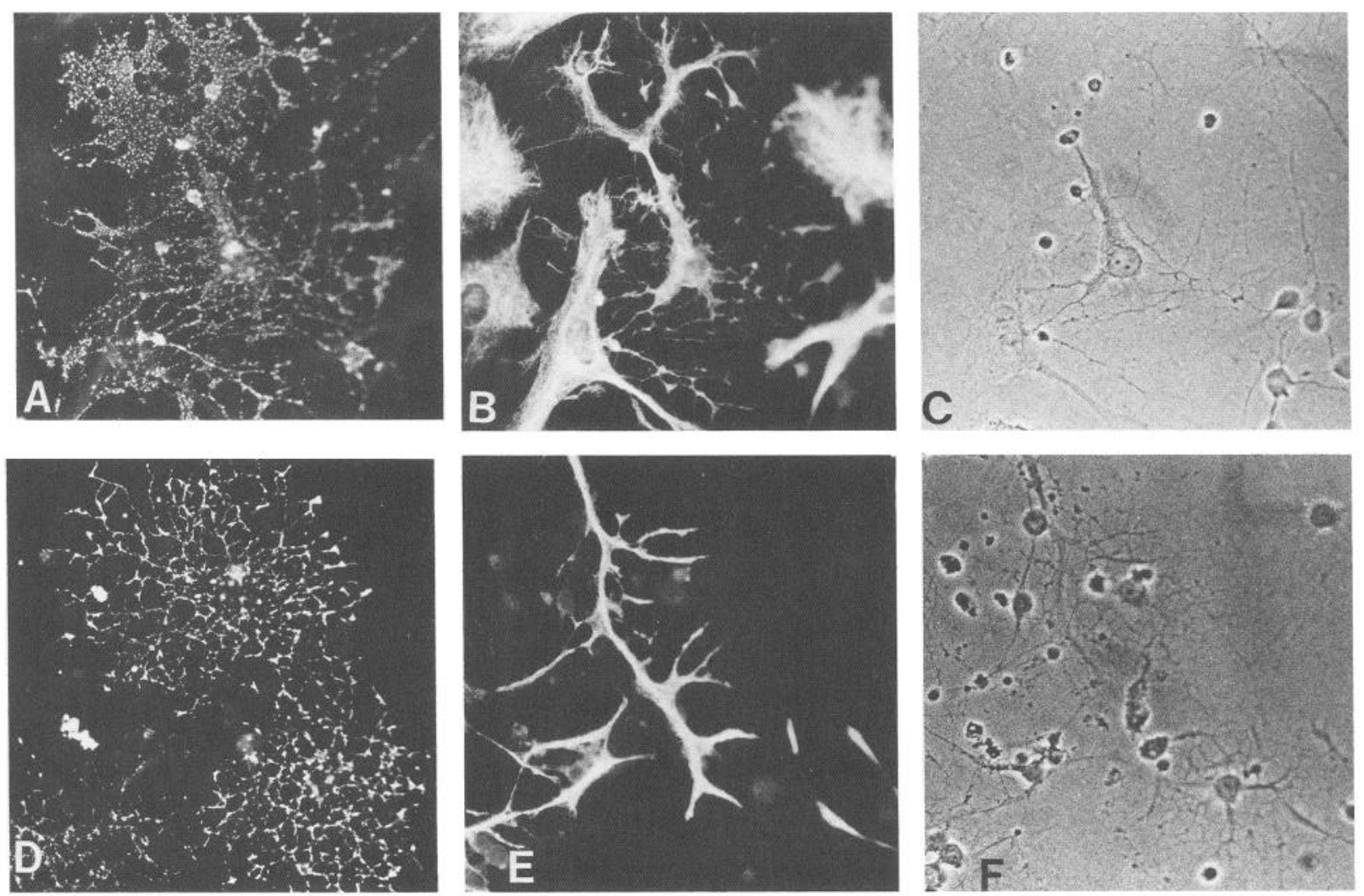

Figure 3. Expression of GFAP immunoreactivity by Mab O4-labeled cells. PND 5 cerebellar cells were grown in either DMEM + 10\% FCS or $\mathrm{N} 2$ medium for $7 \mathrm{~d}$ and labeled with Mab $\mathrm{O} 4$ and rabbit anti-GFAP as described under Materials and Methods. $A$, Mab O4 label; $B$, rabbit antiGFAP label; $C$, phase-contrast, $\times 280$. The cells shown were grown in DMEM $+10 \%$ FCS. $D$, Mab O4 label; $E$, rabbit anti-GFAP label; $F$, phasecontrast, $\times 280$. The cells shown, which are $\mathrm{O} 4$ positive, GFAP negative, were grown in N2 medium.

the NG2-positive, GFAP-positive cells present in the serumcontaining cultures also carry the $\mathrm{O} 4$ antigen on their surfaces.

In the defined medium cultures, between $48-68 \%$ of the NG2labeled cells bound Mab $\mathrm{O} 4$ (Table 2). As was the case in the serum-containing cultures, the NG2-positive, O4-positive cells were a subpopulation of the total O4-labeled cells $(58 \%$ in this case), but only between $0.8-3 \%$ of the O4-labeled cells contained GFAP-like immunoreactivity (Fig. 3, $D-F$ ).

We also examined the NG2-positive cells for the A2B5 antigen, a marker present on bipotential precursor cells in the rat optic nerve (Raff et al., 1983b), most neurons and astrocytes in cultured mouse cerebellum (Schnitzer and Schachner, 1982), and retinal and sensory neurons of the chick (Eisenbarth, et al., 1979). Figures 1 and 2, G-I, and Table 2 show that the NG2-

Table 3. Effects of media are reversible

\begin{tabular}{ccc} 
DIV & Tetanus toxin & GFAP \\
\hline Cells grown for DIV & $1-5$ in DMEM & 10\% FCS and then N2 media \\
7 & $40.3 \pm 6.4$ & $71.7 \pm 15.7$ \\
10 & $57.8 \pm 11.1$ & $58.7 \pm 15.8$ \\
15 & $93.7 \pm 8.8$ & $32.9 \pm 6.4$ \\
Cells grown for DIV $1-5$ in N2 media and then DMEM $+10 \%$ FCS \\
7 & $51.7 \pm 6.4$ & $17.8 \pm 5.8$ \\
10 & $31.2 \pm 8.9$ & $48.6 \pm 14.0$ \\
15 & $23.4 \pm 5.7$ & $75 \pm 7.3$ \\
\hline
\end{tabular}

Data pooled from 4 separate experiments. Cell counts as described in Table 2. labeled cells under both conditions of tissue culture bound Mab A2B5. In our hands, most of the cerebellar neurons and glial cells bound Mab A2B5, so that the NG2-labeled cells comprised a subpopulation of the A2B5-positive cells present in the cultures.

Last, under either of the growth conditions used in this study, the NG2-labeled cells did not contain vimentin-like immunoreactivity (data not shown).

The survival of the NG2-labeled cells in serum-containing medium was poor. After 2 weeks in culture, the total number of NG2-labeled cells declined by two thirds. In defined medium,

\begin{tabular}{|c|c|}
\hline Inhibitor & $\begin{array}{l}\text { NG2-labeled cells with silver } \\
\text { grains ( } \% \text { positive) }\end{array}$ \\
\hline \multicolumn{2}{|l|}{ N2 medium } \\
\hline None & 62.8 \\
\hline $2 \mathrm{~mm} \beta$-alanine & 64.9 \\
\hline $1 \mathrm{~mm}$ DABA & 3.2 \\
\hline \multicolumn{2}{|c|}{$\mathrm{DMEM}+10 \%$ FCS } \\
\hline None & 55.1 \\
\hline $2 \mathrm{~mm} \beta$-alanine & 34.1 \\
\hline $1 \mathrm{~mm}$ DABA & 13.4 \\
\hline
\end{tabular}



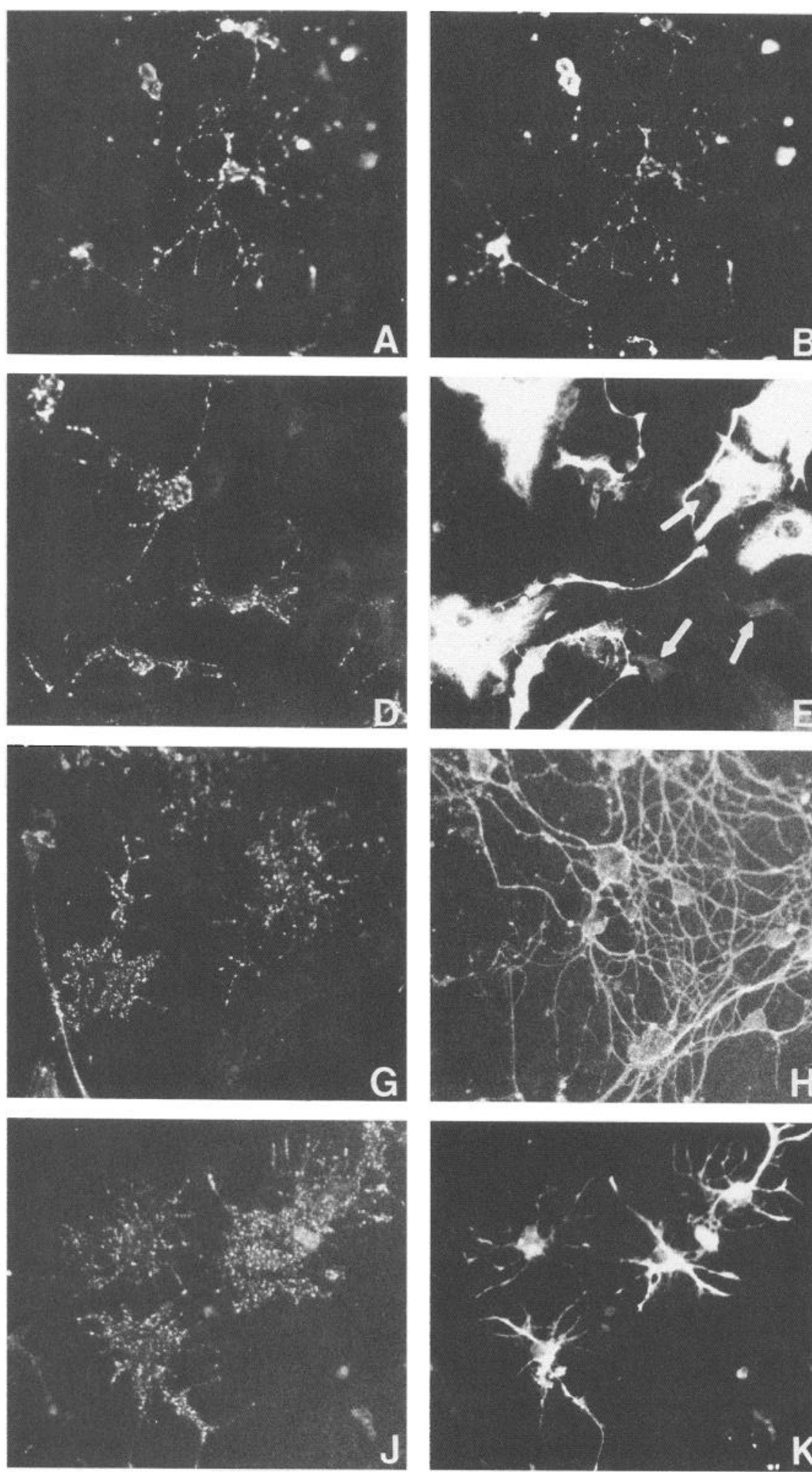
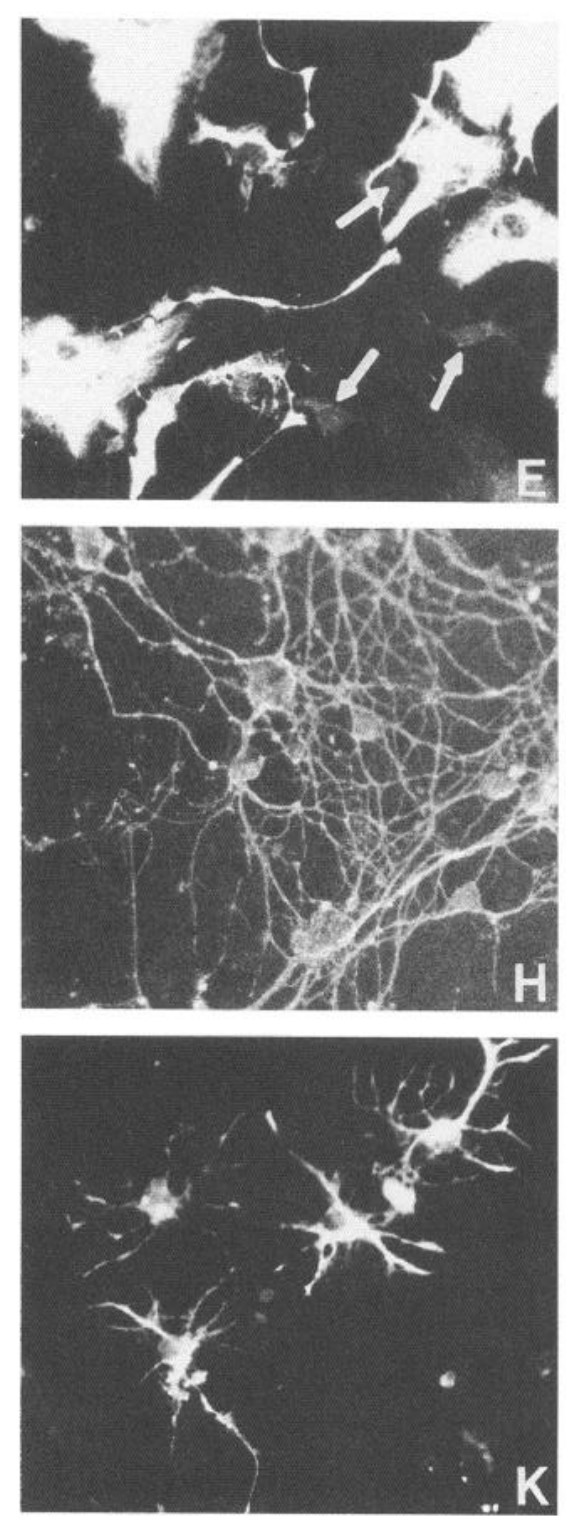
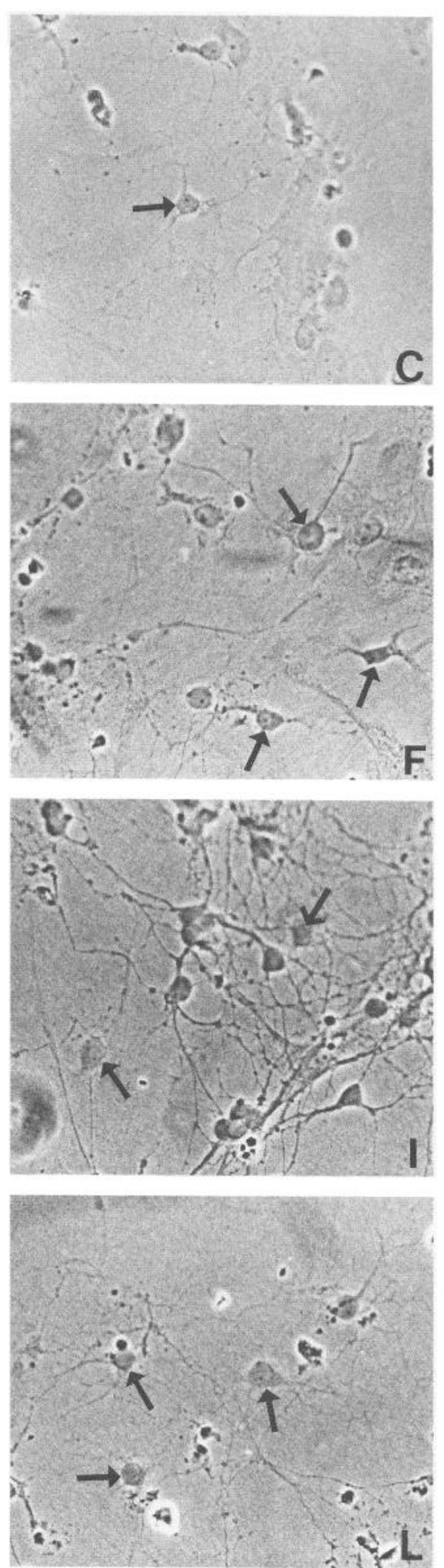

Figure 4. Effects of media on the expression of tetanus toxin binding and GFAP immunoreactivity are reversible. $A$, Rabbit anti-NG2 label; $B$, tetanus toxin label; $C$, phase-contrast, $\times 280$. These cells were grown in DMEM $+10 \%$ FCS for DIV $1-5$ and in N2 medium containing cytosine arabinoside for DIV 5-10. D, Mab anti-NG2 label; $E$, rabbit anti-GFAP label; $F$, phase-contrast, $\times 260$. These cells were grown in DMEM $+10 \%$ FCS for DIV $1-5$ and in N2 medium for DIV 5-7. $G$, Rabbit anti-NG2 label; $H$, tetanus toxin label; $I$, phase-contrast, $\times 260$. These cells were grown in N2 medium for DIV 1-5 and in DMEM + 10\% FCS for DIV 5-7. $J$, Mab anti-NG2 label; $K$, rabbit anti-GFAP label; $L$, phase-contrast, $\times 260$. These cells were grown in N2 medium for DIV $1-5$ and in DMEM $+10 \%$ FCS for DIV 5-7. The arrows indicate the NG2-labeled cells. 

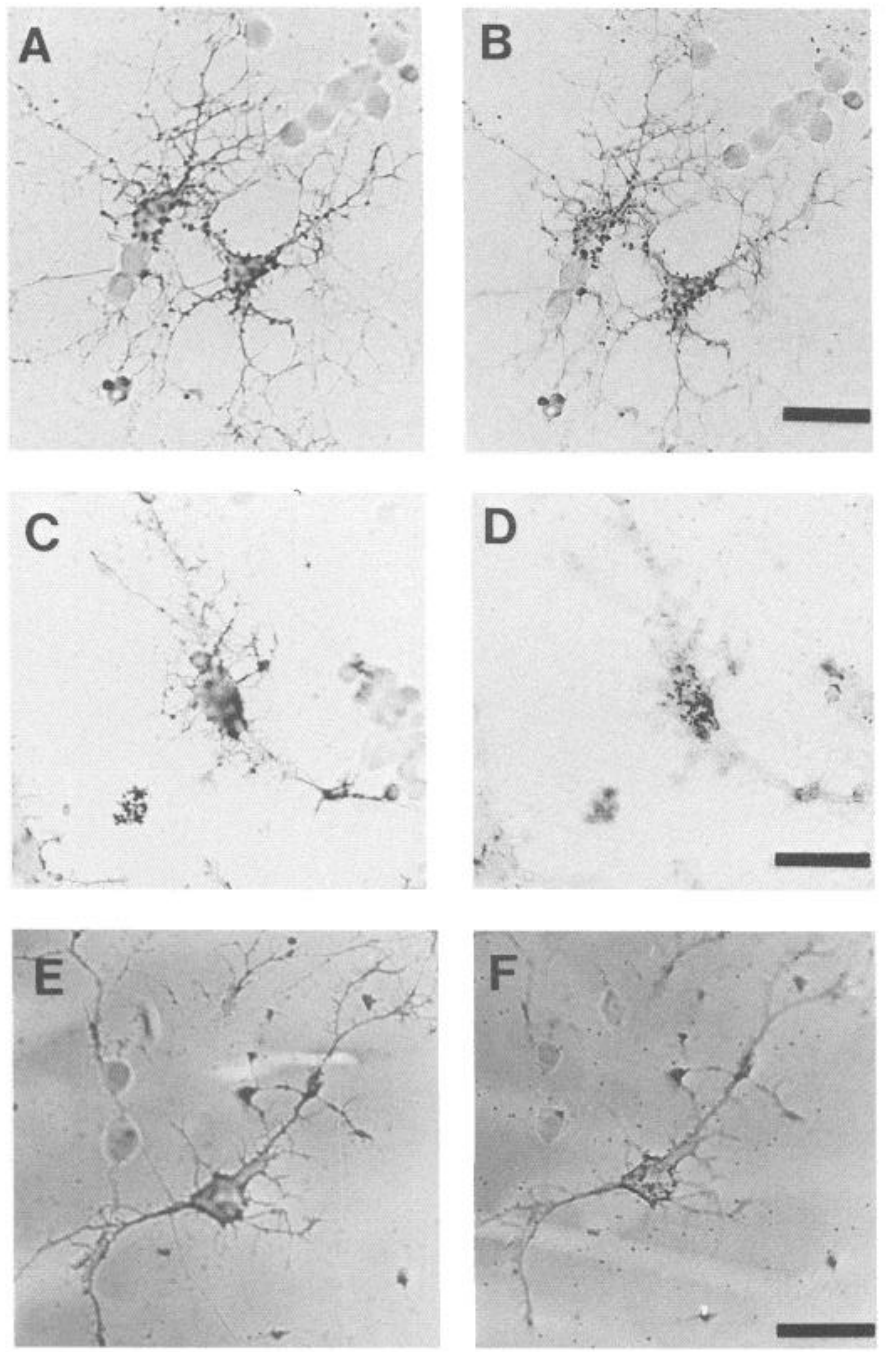

Figure 5. ${ }^{3} \mathrm{H}-\mathrm{GABA}$ uptake by NG2-labeled cells grown in N2 medium. Cells (7 DIV) were labeled with anti-NG2 antibodies and ${ }^{3} \mathrm{H}-$ GABA as described under Materials and Methods. In $A, C$, and $E$, the plane of focus is on the cell surface to reveal the anti-NG2 HRP reaction product and in $B, D$, and $F$, the plane of focus is on the emulsion to reveal the silver grains. $A$ and $B$, Anti-NG2 and ${ }^{3} \mathrm{H}-\mathrm{GABA}$ label, no inhibitors. $C$ and $D$, Cell labeled in the presence of $2 \mathrm{~mm} \beta$-alanine. $E$ and $F$, Cell was labeled in the presence of 1 mM DABA. 7 DIV. Bar, $20 \mu \mathrm{m}$.

however, the total number of NG2-labeled cells was stable, and the variation in the number of labeled cells per culture was between $10-15 \%$ over the 2 week culture period.

\section{Control experiments}

The observations described above suggest that the NG2 antigen may be a surface marker for a class of cells that acquires astrocytic properties in response to FCS but not to defined medium. However, it is possible that the 2 different media used select for different cell types. The NG2 marker may be present on 2 different cell types, one of which survives as astrocytes in serumcontaining medium but does not survive in defined medium. Conversely, the GFAP-negative, tetanus toxin-positive cells observed in the defined medium cultures may be a cell type that cannot survive in serum-containing medium. To rule out this possibility, we performed reversal experiments as follows: cells were grown in either defined medium or serum containing me- dium for $5 \mathrm{~d}$ and were then switched to the other medium. The second medium was supplemented with $10^{-5} \mathrm{M}$ cytosine arabinoside to eliminate cell division. After 2-3 d in the new medium, the phenotype of the NG2-labeled cells was assayed using either tetanus toxin binding or anti-GFAP staining as an index of cell phenotype. Table 3 and Figure 4 show that after being switched from serum-containing medium to defined medium, the NG2-labeled cells acquired tetanus toxin binding sites and lost anti-GFAP immunoreactivity. This trend continued over the next $5 \mathrm{~d}$ of culture. Conversely, cells originally grown in defined medium and then switched to serum-containing medium rapidly acquired anti-GFAP immunoreactivity and lost tetanus toxin binding sites. Thus, the effects of serum on the expression of GFAP-like immunoreactivity and tetanus toxin binding is reversible. These data suggest that the anti-NG2 antibodies are recognizing a single cell type whose differentiation in vitro is sensitive to environmental conditions.

Although the experiment described above appears to rule out the possibility that the culture conditions used select for 1 of 2 different cell types, it is formally possible that changing the medium after $5 \mathrm{~d}$ of culture causes the de novo expression of the NG2 antigen by cells previously scored as NG2 negative. In this way, the NG2-negative, GFAP-positive cells present in the defined medium cultures might be scored as NG2-positive, GFAP-positive cells after switching the medium to DMEM plus $10 \%$ FCS. To rule out this possibility, we labeled cells with rabbit anti-NG2 antibodies on day 5 of culture and then switched the medium. After $24-48 \mathrm{hr}$ in the new medium, we labeled the same cells with Mab anti-NG2 antibodies and with both rhodamine goat anti-rabbit and fluorescein goat anti-mouse antibodies. All cells that had bound the fluorescein-labeled antimouse antibodies also bound the rhodamine-labeled anti-rabbit antibodies (data not shown). Thus, it is unlikely that changing the medium caused either the loss of or the de novo expression of the NG2 antigen by cells present in the cultures.

\section{${ }^{3} \mathrm{H}-\mathrm{GABA}$ uptake by the NG2-labeled cells}

Both cerebellar neurons and astrocytes display high-affinity uptake for GABA in tissue culture (Lasher, 1974; Currie and Dutton, 1980). To examine the functional properties of the NG2labeled cells, we performed high-affinity uptake experiments using ${ }^{3} \mathrm{H}-\mathrm{GABA}$ and combined the autoradiographic demonstration of uptake with anti-NG2 immunocytochemistry. The results of these studies are presented in Table 4 and Figures 5 and 6 . After $7 \mathrm{~d}$ of culture in defined medium, $63 \%$ of the NG2labeled cells displayed high-affinity uptake of ${ }^{3} \mathrm{H}-\mathrm{GABA}$. Uptake was not inhibited by the presence of $2 \mathrm{~mm} \beta$-alanine in the incubation medium but was inhibited in $95 \%$ of the cells by the addition of $1 \mathrm{~mm}$ DABA. When the cerebellar cells were grown in serum-containing medium, $55 \%$ of the cells displayed highaffinity uptake of ${ }^{3} \mathrm{H}-\mathrm{GABA}$. The pharmacology of uptake was significantly different from that seen in defined media, with uptake being partially inhibited by both $\beta$-alanine and DABA.

\section{Discussion}

The experiments described above were undertaken to define the phenotypes exhibited by developing cerebellar cells that carry the NG2 surface antigen. We used dissociated cell cultures in order to analyze the distribution of surface and intracellular markers on a single cell basis. The following conclusions can be made on the basis of the data presented above. (1) The NG2 antigen is a cell surface marker for a subpopulation of the cells 
surviving in dissociated cultures of postnatal rat cerebellum. (2) When the cerebellar cells are grown in medium containing FCS, almost all of the NG2-labeled cells have the properties and morphology of type II or fibrous astrocytes (Raff et al., 1983a). (3) In contrast, when the cerebellar cells are grown in a serumfree, defined medium, most of the NG2-labeled cells do not contain GFAP-like immunoreactivity, and they do not express cell surface markers characteristic of mature oligodendrocytes. This GFAP-negative, GC-negative phenotype likely corresponds to the smooth protoplasmic astrocytes we have identified by anti-NG2 immunocytochemistry in the intact cerebellum (Levine and Card, 1987). These observations provide evidence for plasticity among developing cerebellar astroglial cells and suggest that the acquisition of phenotypic properties by developing glia can be modified by environmental conditions. In addition, these studies suggest that smooth protoplasmic astrocytes may arise from a cell lineage that is qualitatively similar to the O-2A lineage (Raff et al., 1983b).

These conclusions are based on the comparative distribution of cell surface and intracellular marker antigens on the NG2labeled cells, as well as the pharmacology of GABA uptake, a functional property associated with both neurons and glial cells (for review, see Iversen and Kelly, 1975). We used a wide panel of marker antigens, some of which are cell type specific. The presence of anti-GFAP immunoreactivity denotes an astrocytic phenotype (Bignami et al., 1972), and cell surface GC and the $\mathrm{O} 1$ antigen are phenotypic markers for oligodendrocytes (Raff et al., 1978; Sommer and Schachner, 1981). Other markers used here have a wide distribution and cannot, in themselves, be used to determine a cellular phenotype. Tetanus toxin binding is associated with neurons (Mirsky et al., 1977) and some astrocytes and immature oligodendrocytes in developing optic nerve (Raff et al., 1983b). The A2B5 antigen is carried by chick retinal and sensory neurons (Eisenbarth et al., 1979), immature glial cells in developing rat optic nerve (Raff et al., 1983b) and neurons and glial cells in cultures of mouse cerebellum (Schnitzer and Schachner, 1982). Considering the generality of these 2 markers, it is not surprising that considerable numbers of the NG2-labeled cells also bind both tetanus toxin and Mab A2B5.

The significance of the expression of the $\mathrm{O} 4$ antigen by approximately half of the NG2-labeled cells is not understood. The $\mathrm{O} 4$ antigen was originally thought to be a surface marker for immature oligodendrocytes. In cultures of mouse cerebellum, Mab O4 recognized a class of GFAP-negative cells that, with increasing time in culture, became GC positive (Schachner et al., 1981). In our serum-containing cultures, however, between $20-40 \%$ of the O4-positive cells displayed GFAP-like immunoreactivity. Whether this discrepancy results from a species difference (rat versus mouse), an age difference (PND 5 versus PND 7), or from a difference in the culture conditions is unknown. The $\mathrm{O} 4$ antigen, however, is present on some GFAPpositive cells in cultures of optic nerve (Sommer and Noble, 1986) and also recognizes a class of non-neuronal cells of the chick ciliary ganglia that are capable of displaying neuronal properties (Rohrer and Sommer, 1983). These considerations suggest that the $\mathrm{O} 4$ antigen may not necessarily be a marker only for immature oligodendrocytes or their precursors. Although the full significance of the $\mathrm{O} 4$ antigen is not yet known, it may be a marker for an immature and plastic state common to several types of developing glia. It will be of interest to determine whether NG2-positive cells isolated from adult animals also express the $\mathrm{O} 4$ antigen.
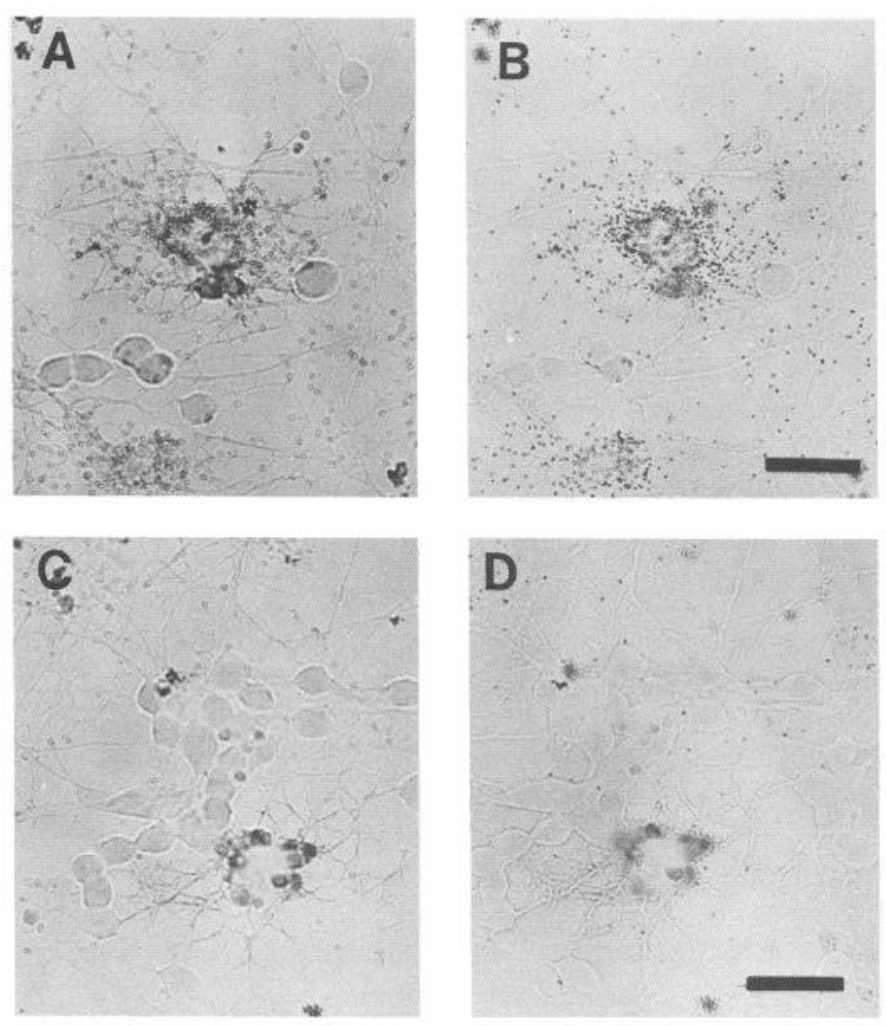

Figure 6. ${ }^{3} \mathrm{H}-\mathrm{GABA}$ uptake by NG2-labeled cells grown in DMEM + $10 \%$ FCS for $7 \mathrm{~d}$. Cells were labeled and photographed as in Figure 5. $A$ and $B$, Anti-NG2 and ${ }^{3} \mathrm{H}-\mathrm{GABA}$ label, no inhibitors. $C$ and $D$, An NG2-labeled cell whose uptake was inhibited by $1 \mathrm{~mm}$ DABA. Bar, 20 $\mu \mathrm{m}$.

The ability of cerebellar cells to concentrate GABA in vivo and in vitro has been well documented (Hökfelt and Ljungdahl, 1970; Lasher, 1974; Currie and Dutton, 1980). Traditionally, GABA uptake in neurons and glia has been distinguished on the basis of the differential sensitivity of these cell types to inhibitors, $\beta$-alanine being a competitive inhibitor of glial uptake (Schon and Kelly, 1974) and DABA being an inhibitor of neuronal uptake (Iversen and Kelly, 1975). However, recent evidence suggests that these distinctions may not be as rigorous as originally thought. A subpopulation of cerebellar astrocytes has been reported to exhibit a neuronal type of uptake (Johnstone et al., 1985). Embryonic brain oligodendrocytes can take up GABA, and this uptake is inhibited by DABA but not by $\beta$-alanine (Reynolds and Herschkowitz, 1984). Despite these interpretational difficulties, our results demonstrate, first, that the NG2-labeled cells have at least one functional property associated with astrocytes and, second, that this functional property can be modified by the in vitro environmental conditions.

In serum-containing cultures, the cells identified by binding of the anti-NG2 antibodies have an astrocytic phenotype. Morphologically, the cells are characterized by a prominent nucleus surrounded by a scant rim of cytoplasm that is often difficult to resolve with phase optics. When visualized by fluorescent staining with the anti-NG2 antibodies, many short branched processes symmetrically arrayed around the soma are apparent. Although these morphological characteristics are shared by astrocytes and oligodendrocytes, the fact that, after 1 week in culture, $68 \%$ of the NG2-labeled cells contained GFAP-like immunoreactivity but only about $1 \%$ of the cells were labeled 
with either anti-GC or Mab O1 indicates that the NG2-labeled cells are indeed astrocytes rather than oligodendrocytes. Between one and two thirds of the NG2-labeled cells were labeled with $\mathrm{Mab} \mathrm{O} 4$, and, early in the culture period, the cells bound tetanus toxin and Mab A2B5. These cells also displayed a highaflinity uplake mechanism for ${ }^{3} \mathrm{H}-\mathrm{GABA}$, and this uptake was partially inhibited by both $\beta$-alanine and DABA. Despite a low level of tetanus toxin binding, the NG2-positive cells grown in serum-containing medium appear identical to the type II, or fibrous astrocytes that have been well characterized in cultures of developing rat optic nerve (Raff et al., 1983a).

In defined medium, the NG2-labeled cells express phenotypic properties that differ from those exhibited in serum-containing cultures. Over half the cells have tetanus toxin binding sites on their surfaces but only a very small percentage of the cells display GFAP-like immunoreactivity. As was the case for cells grown in serum, the NG2-labeled cells bind Mab A2B5 and O4, but few of the cells express the surface markers characteristic of mature oligodendrocytes (GC or the $\mathrm{O} 1$ antigen). Although the NG2-labeled cells are capable of concentrating GABA when grown in defined medium, uptake was inhibited by DABA but not by $\beta$-alanine. Morphologically, the cells have fewer and longer processes, resulting in a stellate rather than a bushy appearance. These cells have a striking resemblance to the NG2labeled cells identified immunocytochemically in the developing and mature cerebellum (Levine and Card, 1987). This GFAPnegative, GC-negative phenotype likely corresponds to the phenotype of smooth protoplasmic astrocytes. Thus, it appears that, in the developing cerebellum, the NG 2 antigen may be a marker for an astrocytic lineage that can give rise to both fibrous astrocytes and smooth protoplasmic astrocytes depending on environmental conditions.

Our conclusions regarding the phenotypic plasticity of the developing NG2-labeled cells assume that prior to dissociation these cells comprise a homogeneous population. This assumption is supported by several observations. First, in the intact adult cerebellum, the anti-NG2 antibodies label a distinct and homogeneous-appearing class of cells with a characteristic stellate morphology (Levine and Card, 1987). Second, in the PND5 cerebella used here, the anti-NG2 antibodies also label a homogeneous-appearing population of cells that are found throughout the intact cerebellum. Third, at early times in culture ( $3 \mathrm{~d}$ or less), there is little difference in the quantitative expression of the cell surface markers analyzed in this study under either of the growth conditions used. Last, the environmentally modulated expression of tetanus toxin binding sites and GFAPlike immunoreactivity by the NG2-labeled cells is reversible during the first $5 \mathrm{~d}$ of culture. Thus, it is likely that the NG2 antibodies identify a single class of developing cells whose phenotypic properties diverge when grown under 2 different sets of in vitro conditions.

Since the NG2-labeled cells can express GFAP-containing filaments under the influence of serum, what then prevents this expression during cerebellar development? At present, we can only speculate as to what factors might regulate glial histogenesis in vivo. It is possible that some interaction or contact between nascent NG2-positive cells and growing parallel fibers of the molecular layer provides one or more histogenic signals that result in the repression of the ability of the NG2 cells to synthesize and assemble GFAP filaments. Interactions between cerebellar neurons and glial cells are thought to play a role in the differentiation of cerebellar astrocytes (Hatten, 1985). Consis- tent with this hypothesis, we have observed that when cerebellar cells are grown at high density $\left(10^{5} \mathrm{cells} / \mathrm{cm}^{2}\right)$ in medium containing $10 \%$ FCS, many of the NG2-labeled cells were not colabeled with anti-GFAP and they had a stellate, rather than a bushy, morphology (unpublished observations). Although it is possible that at high density many of the NG2-positive astrocytes revert to a flattened epithelioid morphology (Wilkin et al., 1983), this model provides a framework for further experimentation.

The developmental plasticity of cerebellar cells demonstrated here is similar to the phenotypic plasticity of glial cells in the developing optic nerve. In the optic nerve, a precursor cell, termed an $\mathrm{O}-2 \mathrm{~A}$ progenitor cell, develops into either a fibrous astrocyte or an oligodendrocyte depending on tissue culture conditions (Raff et al., 1983b). The fibrous, or type II, astrocytes that develop in serum-containing cultures of optic nerve are tetanus toxin positive and Mab A2B5 positive and contain GFAP immunoreactivity (Raff et al., 1983a). The NG2-labeled cells of the developing cerebellum adopt a similar phenotype in serum-containing cultures, although the percentage of cells that bind tetanus toxin is lower than in cultures of optic nerve. Under the influence of a defined medium, O-2A progenitor cells develop into GC-positive oligodendrocytes. In contrast, the NG2-labeled cells of the cerebellum fail to express either GC or the $\mathrm{O} 1$ antigen when grown in a serum-free, chemically defined medium. As discussed above, this cell type may be the smooth protoplasmic astrocyte we have identified in situ (Levine and Card, 1987). The similarities between the development of glia in the optic nerve and the cerebellum suggest that smooth protoplasmic astrocytes may comprise a third member of the $\mathrm{O}-2 \mathrm{~A}$ lineage family, one that develops in mixed cultures containing both neurons and glial cells.

There are other possible interpretations of these results. The NG2-labeled cells present in the defined medium cultures may be oligodendrocytes that fail to differentiate fully and consequently do not express cell surface GC. This seems unlikely since there are numerous GC-positive and O1-positive oligodendrocytes in our cultures. Thus, the defined medium used here is permissive for oligodendrocyte differentiation. An additional possibility is that some of the NG2-positive, O4-positive cells represent an intermediate stage in oligodendrocyte development; that is, some oligodendrocytes may transiently express an O4-positive, NG2-positive, GC-negative phenotype prior to differentiating into an O4-negative, NG2-negative, GCpositive cell. This possibility is supported by the observation that in cultures of developing optic nerve, some of the NG2labeled cells can develop into NG2-negative, GC-positive oligodendrocytes (Stallcup and Beasley, 1987). These diverse findings using cells isolated from separate areas of the CNS could be reconciled if NG2-labeled cells participated in a self-renewing lineage in which NG2-labeled cells (or their precursors) divide slowly to generate both a stable number of NG2-positive cells (that become smooth protoplasmic astrocytes) and a transient population of NG2-positive cells that eventually differentiate into NG2-negative oligodendrocytes. Experiments using ${ }^{3} \mathrm{H}$ thymidine autoradiography to identify dividing cells are currently in progress to test this hypothesis.

Last, our results point out that glial development may proceed differently in different brain regions. In the developing optic nerve, NG2-labeled cells participate in the O-2A lineage developing into either type II astrocytes or oligodendrocytes (Rafl et al., 1983b; Stallcup and Beasley, 1987). In the developing cer- 
ebellum however, the NG2-labeled cells develop into different types of astrocytes but rarely, if ever, express oligodendrocytic properties. Thus, cerebellar cultures must contain factors that can influence the histogenesis of the NG2-labeled glial cells in a manner different from that which occurs in optic nerve cultures. Since optic nerve cultures are aneuronal, it is logical to suppose that cerebellar interneurons may be the source of these histogenic signals.

\section{References}

Abney, E. R., P. P. Bartlett, and M. C. Raff (1981) Astrocytes, ependymal cells, and oligodendrocytes develop on schedule in dissociated cell cultures of embryonic rat brain. Dev. Biol. 83: 301-310.

Bignami, A., L. F. Eng, D. Dahl, and C. T. Uyeda (1972) Localization of the glial fibrillary acidic protein in astrocytes by immunofluorescence. Brain Res. 43: 429-435.

Bottenstein, J. E., and G. H. Sato (1979) Growth of a rat neuroblastoma cell line in serum-free supplemented medium. Proc. Natl. Acad. Sci. USA 76: 514-517.

Currie, D. N., and G. R. Dutton (1980) [ $\left.{ }^{3} \mathrm{H}\right]$ GABA uptake as a marker for cell type in primary cultures of cerebellum and olfactory bulb. Brain Res. 199: 473-481.

Dellagi, K., J. C. Brouet, J. Perreau, and D. Paulin (1982) Human monoclonal IgM with autoantibody activity against intermediate filaments. Proc. Natl. Acad. Sci. USA 79: 446-450.

Eisenbarth, G. S., F. S. Walsh, and M. Nirenberg (1979) Monoclonal antibody to a plasma membrane antigen of neurons. Proc. Natl. Acad. Sci. USA 76: 4913-4917.

Hatten, M. E. (1985) Neuronal regulation of astroglial morphology and proliferation in vitro. J. Cell Biol. 100: 384-396.

Hökfelt, T., and A. Ljungdahl (1970) Cellular localization of $\gamma$-aminobutyric acid $\left[{ }^{3} \mathrm{H}-\mathrm{GABA}\right]$ in rat cerebellar cortex. An autoradiographic study. Brain Res. 22: 391-399.

Iversen, L. L., and J. S. Kelly (1975) Uptake and metabolism of $\gamma$-aminobutyric acid by neurones and glial cells. Biochem. Pharmacol. 24: 933-938.

Johnstone, S. R., G. Levi, G. P. Wilkin, A. Schneider, and M. T. Ciotti (1985) Subpopulations of rat cerebellar astrocytes in primary culture: Morphology, cell surface antigens and $\left[{ }^{3} \mathrm{H}\right] \mathrm{GABA}$ transport. Dev. Brain Res. 24: 63-75.

Lasher, R. S. (1974) The uplake of $\left[{ }^{3} \mathrm{H}\right] \mathrm{GABA}$ and differentiation of stellate neurons in cultures of dissociated postnatal rat cerebellum. Brain Res. 69: 235-254.

Lazerides, E. (1980) Intermediate filaments as integrators of cellular space. Nature 283: 249-256.

Levine, J. M., and J. P. Card (1987) Light and electron microscopic localization of a cell surface antigen (NG2) in the rat cerebellum: Association with smooth protoplasmic astrocytes. J. Neurosci. 7:27112720.

Levine, J. M., L. Beasley, and W. B. Stallcup (1984) The D1.1 antigen: A cell surface marker for germinal cells of the central nervous system. J. Neurosci. 4: 820-831.

Mirsky, R., L. M. B. Wendon, P. Black, C. Stolkin, and D. Bray (1977)
Tetanus toxin: A cell surface marker for neurones in culture. Brain Res. 148: 251-259.

Raff, M. C., R. Mirsky, K. L. Fields, R. P. Lisak, S. H. Dorfman, D. H. Silberberg, N. A. Gregson, S. Leibowitz, and M. C. Kennedy (1978) Galactocerebroside is a specific antigenic marker for oligodendrocytes in culture. Nature 277: 813-816.

Raff, M. C., E. R. Abney, J. Cohen, R. Lindsay, and M. Noble (1983a) Two types of astrocytes in cultures of developing rat white matter: Differences in morphology, surface gangliosides, and growth characteristics. J. Neurosci. 3: 1289-1300.

Raff, M. C., R. H. Miller, and M. Noble (1983b) A glial progenitor cell that develops in vitro into an astrocyte or an oligodendrocyte depcnding on culturc medium. Nature 303: 390-396.

Reynolds, R., and N. Herschkowitz (1984) Uptake of [ $\left.{ }^{3} \mathrm{H}\right]$ GABA by oligodendrocytes in dissociated brain cell culture: A combined autoradiographic and immunocytochemical study. Brain Res. 322: 1731.

Rohrer, H., and I. Sommer (1983) Simultaneous expression of neuronal and glial properties by chick ciliary ganglion cells during development. J. Neurosci. 3: 1683-1693.

Schachner, M., S. K. Kim, and R. Zehnle (1981) Developmental expression in central and peripheral nervous system of oligodendrocyte cell surface antigens ( $\mathrm{O}$ antigens) recognized by monoclonal antibodies. Dev. Biol. 83: 328-338.

Schnitzer, J., and M. Schachner (1982) Cell type specificity of a neural cell surface antigen recognized by the monoclonal antibody A2B5. Cell Tissue Res. 224: 625-636.

Schnitzer, J., W. W. Franke, and M. Schachner (1981) Immunocytochemical demonstration of vimentin in astrocytes and ependymal cells of developing and adult mouse nervous system. J. Cell Biol. 90 . $435-447$.

Schon, F., and J. S. Kelly (1974) The characterization of $\left[{ }^{3} \mathrm{H}\right] \mathrm{GABA}$ uptake into satellite glial cells of rat sensory ganglia. Brain Res. 66: 289-300.

Sommer, I., and M. Noble (1986) Plasticity and commitment in oligodendrocyte development. Soc. Neurosci. Abstr. 12: 1585.

Sommer, I., and M. Schachner (1981) Monoclonal antibodies (O1 to 04) to oligodendrocyte surfaces: An immunocytological study in the central nervous system. Dev. Biol. 83: 311-327.

Stallcup, W. B. (1981) The NG2 antigen, a putative lineage marker: Immunofluorescent localization in primary cultures of rat brain. Dev. Biol. 83: 154-165.

Stallcup, W. B., and L. Beasley (1987) Bipotential glial precursor cells in optic nerve express the NG2 proteoglycan. (submitted).

Stallcup, W. B., L. Beasley, and J. Levine (1983) Cell-surface molecules that characterize different stages in the development of cerebellar interneurons. Cold Spring Harbor Symp. Quant. Biol. 48: 761-774,

Temple, S., and M. C. Raff (1985) Differentiation of a bipotential glial progenitor cell in single cell microculture. Nature 313: 223-225.

Wilkin, G. P., G. Levi, S. R. Johnstone, and P. N. Riddle (1983) Cerebellar astroglial cells in primary culture: Expression of different morphological appearances and different ability to take up $\left[{ }^{3} \mathrm{H}\right] \mathrm{D}$ aspartate and [ $\left.{ }^{3} \mathrm{H}\right] \mathrm{GABA}$. Dev. Brain Res. 10: 265-277.

Wilson, S.-S., E. E. Baetge, and W. B. Stallcup (1980) Antisera specific for cell lines and mixed neuronal and glial properties. Dev. Biol. 83: 146-153. 